\title{
REPRESENTAÇÕES DE ATORES SOCIAIS EM \\ IMAGENS DE LIVROS DIDÁTICOS DE ESPANHOL: \\ UM OLHAR CRIITICO PARA QUESTÕES RACIAIS
}

\author{
SOCIAL ACTORS REPRESENTATIONS IN IMAGES OF \\ SPANISH LANGUAGE TEXTBOOKS: \\ A CRITICAL LOOK AT THE RACIAL ISSUES
}

\section{Carolina Parrini Ferreira ${ }^{*}$}

\begin{abstract}
RESUMO
Este artigo apresenta uma análise discursivo-crítica das representações de raça em quatro coleções de livros didáticos (LD) de Espanhol para o Ensino Fundamental: iAdelante! (2002), Saludos (2008), Ventana al español (2011) e Contraseña (2015), todas já utilizadas em escolas de Florianópolis/SC. A análise compreende um levantamento quantitativo, a fim de verificar a frequência com que pessoas negras, indígenas, asiáticas e brancas são contempladas, e uma apreciação qualitativa/interpretativa em relação aos papéis sociais e ao modo como os atores sociais são representados (VAN LEEUWEN, 2008) nas imagens presentes nas coleções. O suporte teórico-analítico que embasa o estudo é a Análise de Discurso Crítica (FAIRCLOUGH, 2016; VIEIRA e RESENDE, 2016 e MELO, 2009), além de referências sobre discurso e raça (VAN DIJK, 2008; FERREIRA, 2019; ENEVAN e JOVINO, 2019; e outros) e sobre decolonização (RESENDE, 2019 e VIEIRA, 2019). Resumidamente, os resultados mostram que, ao longo do tempo, a frequência de algumas raças aumenta sutilmente, enquanto outras se mantém predominante ou apagada; há também aumento da variedade de papéis sociais relacionados a algumas raças, embora muitas representações reforcem/ reproduzam estereotipias, sinalizando alguns avanços e muitos desafios a serem ainda superados para que se possa alcançar uma escolarização verdadeiramente antirracista.
\end{abstract}

Palavras-chave: representação de raça; livro didático de Espanhol; imagens; análise discursivo-crítica.

\section{ABSTRACT}

This article provides a critical discursive analysis of race representation in four collections of Spanish language textbooks to elementary schools in Florianópolis/SC: iAdelante! (2002); Saludos (2008); Ventana al español (2011); and Contraseña (2015). The analysis encompasses a quantitative survey, in order to verify the frequency to which black, indigenous, asian, and white people are portrayed; as well as qualitative/interpretative appraisal regarding social roles, and how these social actors are depicted (VAN LEEUWEN, 2008) in the books images. The theoretical and analytical framework for the study is the Critical Analysis Discourse (FAIRCLOUGH, 2016; VIEIRA \& RESENDE, 2016 and MELO, 2009), discourse and race references (VAN DIJK, 2008; FERREIRA, 2019; ENEVAN \& JOVINO, 2019; and others), and decolonization (RESENDE, 2019 and VIEIRA, 2019). Briefly, the results showed that, with time, the frequency in which some races appear subtly increases; while others are predominantly inconspicuous. There is also an increment in the variety of social roles applied to some races, although many of such representations reinforce or reproduce stereotypes; signaling a few advances but also many challenges to overcome in order to achieve a truly antiracist education.

Keywords: race representation; Spanish language textbooks; images; critical discursive analysis.

\section{INTRODUÇÃO}

Analisar e problematizar ideologias propagadas em materiais didáticos não é tema novo e nem recente, sobretudo no que diz respeito a questões étnico-raciais. Conforme salientam Silva et al. (2014), desde o final da década de setenta, o Movimento Negro Unificado já reivindicava a eliminação de conteúdos racistas dos livros didáticos (doravante, LD) e de outras práticas escolares. Nas décadas seguintes, as políticas do Programa Nacional do Livro Didático (PNLD) e a criação de dispositivos legais (Lei n ${ }^{\circ} 10.639$ de 9 de janeiro de 2003, que estabelece a obrigatoriedade do ensino da história e cultura afro-brasileira, por exemplo) também vem reafirmando a intenção de eliminar estereótipos e preconceitos dos LD, com vistas a promover uma escolarização que respeite as diversidades. No âmbito da academia, são inúmeras as pesquisas que problematizam as sub-representações de determinadas etnias e as consequências disso no processo de escolarização e na construção e/ou manutenção de um imaginário social discriminatório (alguns exemplos serão vistos nos estudos resenhados na seção 1).

\footnotetext{
* Universidade Federal de Santa Catarina (UFSC), Florianópilis, SC, Brasil. carolparrini08@gmail.com Orcid: https://orcid.org/0000-0002-7767-9731
} 
Entretanto, por mais numerosas que sejam as publicações e os dispositivos legais, os estudos mostram que os LD de diferentes disciplinas escolares ainda reproduzem estereótipos negativos que reverberam ideologias racistas, através de diversos mecanismos discursivos, verbais e não-verbais. Acontece que nem sempre determinados conteúdos são identificados como racistas, pois trata-se de um problema estrutural, com diferentes formas de manifestação, sendo algumas explícitas e outras mais sutis, implícitas, e não identificáveis com clareza por indivíduos pertencentes a uma sociedade profundamente racista e negacionista deste grave problema sócio-histórico-cultural (cf. VAN DIJK, 2008 e SILVA, 2011)

Conforme alerta van Dijk (2008), as desigualdades étnicas e raciais não resultam de uma ou outra prática discriminatória, mas sim de várias práticas integradas, em inúmeros gêneros de discurso e eventos comunicativos. Sendo assim, os LD, como textos produzidos por atores sociais (autores) que fazem parte de uma sociedade racista, são apenas mais um gênero dentre tantos outros que formam uma rede de práticas sociais nas quais o racismo é reproduzido, mantido e ainda resistente às iniciativas de mudança.

Sobre práticas sociais que reverberam racismo, é importante destacar que uma das motivações para o desenvolvimento do presente estudo (bem como de outras ações acadêmicas) surgiu após observar frequentes casos envolvendo racismo na Universidade Federal de Santa Catarina (UFSC). Frente à recorrência desses acontecimentos, diversas ações afirmativas têm sido postas em execução pela comunidade acadêmica da UFSC, todas com o objetivo de conscientizar sobre e combater o racismo e seus efeitos na comunidade acadêmica em questão.

Em meio às diversas ações antirracistas, no âmbito do ensino, vale destacar a realização de um minicurso sobre representações raciais em LD de Espanhol, na IX Semana Acadêmica de Letras da UFSC, em 2015. O destaque desta ação se dá pelo seguinte fato: naquela oportunidade, notou-se certa reação de surpresa por parte dos participantes do minicurso, os quais disseram nunca terem percebido a predominância de pessoas brancas e/ou as representações estereotipadas das demais raças nos LD (nem em outros gêneros, como propagandas, novelas etc). Tal reação dos participantes foi, no mínimo, surpreendente e preocupante, uma vez que se tratava de um público majoritariamente jovem, altamente escolarizado, que tem acesso a meios de informação e que (acredita-se) tem condições de estar inteirado dos debates acerca das questões raciais existentes na sociedade em que vive. Entretanto, ficou evidente que os participantes não percebiam, até então, a manifestação do racismo quando este não se apresentava de forma explícita, como é o caso dos LD, em que o discurso racista aparece de forma velada através, por exemplo, do apagamento das diversidades raciais e da predominância da raça branca, ou de representações estereotipadas dos não-brancos.

Considerando que a audiência do referido minicurso era de graduandos do curso de Letras, e que, certamente, seriam futuros professores, é de extrema relevância promover uma reflexão e uma visão crítica frente às ideologias presentes nos $\mathrm{LD}$, explicitando os mecanismos discursivos que servem à reprodução e perpetuação de desigualdades sociais, dentre elas o racismo.

Dessa maneira, o presente artigo busca evidenciar, através de uma análise discursivo-crítica, as representações de raça em imagens de quatro coleções de LD de Espanhol, observando os avanços ocorridos e as práticas racistas ainda persistentes em LD produzidos e comercializados ao longo de mais de 10 anos. A análise compreende um levantamento quantitativo, a fim de verificar a frequência com que pessoas negras, indígenas, asiáticas e brancas são contempladas, e uma apreciação qualitativa/interpretativa em relação aos papéis sociais e ao modo como os atores sociais são representados nas imagens presentes nas coleções. Com isso, objetiva-se contribuir, em forma de ação acadêmica, com os estudos e outras ações antirracistas que buscam desvelar, desconstruir e desnaturalizar modos de pensar e agir condicionados pelo racismo, sensibilizando os leitores para certas questões presentes (e ausentes) nos LD que circulam no mercado.

Para tanto, este artigo está organizado em cinco seções, nas quais apresentam-se: 1. alguns estudos recentes sobre representações de raça em LD de Espanhol; 2. os pressupostos teórico-analíticos que orientam a discussão; 3. a descrição das coleções analisadas e das categorias de análise; 4. os dados obtidos e uma explanação sobre os resultados da análise; e 5 . as considerações finais do estudo.

\section{REPRESENTAÇÕES DE RAÇA EM LD DE ESPANHOL: ESTUDOS RECENTES}

Nesta seção, são resenhados alguns estudos recentes (2014 a 2019) cuja temática central é a mesma do presente artigo: análise de representações raciais em LD de Espanhol. Esses estudos se complementam na medida 
em que apresentam diferentes abordagens investigativas e analisam materiais distintos, mas têm uma temática em comum, o que contribui significativamente para a literatura sobre o tema. Os resultados dessas pesquisas servirão de base comparativa para os dados encontrados neste artigo, com vistas a fornecer mais informações sobre o tema em questão.

Jovino (2014) analisou a representação de negros e negras em imagens na coleção Enlaces (2010) e identificou aspectos positivos e negativos. Em uma unidade do primeiro volume, a pesquisadora observou representações positivas de negros e negras, por exemplo, em imagens que exibiam: crianças, jovens e adultos negros em primeiro plano, pessoas negras inseridas em diferentes contextos sociais com outros grupos étnico-raciais, expressões faciais de alegria em personagens negros e apresentação de modelos negros ao tratar de moda. No último volume, a autora destaca importantes representações: uma criança negra caracterizada como cientista, uma imagem do geógrafo Milton Santos e uma fotografia de uma militante indígena da Guatemala.

Por outro lado, a análise de Jovino (2014) mostrou também que a representação imagética de negros é bem inferior que a de brancos: 56 pessoas negras e 312 pessoas brancas, em toda a coleção. Além disso, verificou que a representação de grupos de pessoas negras é praticamente inexistente, havendo apenas duas famílias negras, e uma indígena, dentre 11 imagens de grupos familiares. Em temáticas como "esportes", pessoas negras são contempladas apenas no futebol.

Como pode ser visto nos dados de Jovino, há uma disparidade entre representações de pessoas negras e brancas, com claras desvantagens para os negros (e para os indígenas), haja vista sua representação minoritária e certos papéis sociais estereotipados que lhes são atribuídos. Por fim, a autora ressalta o papel da representação e da imagem na construção do imaginário social, bem como o papel dos LD no contexto da educação, e destaca a relevância das pesquisas que buscam trazer análises de representações, pois contribuem para construir práticas escolares antirracistas, que contemplem a diversidade e repensem estereótipos.

Sobre construção do imaginário social, vale destacar algumas observações do estudo de Silva et al. (2014). Através de uma coleta de dados sobre rememoração de representação do negro em LD, esses pesquisadores identificaram os pontos de vista de alunos negros de $5^{\mathrm{a}}$ a $7^{\mathrm{a}}$ séries, de uma escola pública estadual no Paraná. As crianças fizeram desenhos e responderam a uma entrevista sobre quais eram suas lembranças a respeito das imagens de pessoas negras nos LD. O resultado da investigação mostrou que, tanto pelos desenhos como pelas falas das crianças, a percepção que elas têm é a de que os LD trazem imagens estereotipadas e estigmatizantes sobre negros. A maioria dos desenhos retratava cenas da escravidão, com pessoas negras sendo castigadas, amarradas em tronco, levando chibatadas. Nenhum aluno retratou imagens que mostrassem pessoas negras como membros atuantes na sociedade.

Pelos resultados da pesquisa de Silva et al. (2014) pode-se imaginar que tipos de identidades sociais são construídas sobre pessoas negras, por meio dos discursos que circulam no ambiente escolar, dentre os quais está o dos LD, que ocupam um espaço significante na escolarização, pois são vistos como fontes de conhecimento, e têm seu discurso legitimado e revestido de poder.

Souza (2016) discutiu as representações de negras e negros em duas coleções de LD para o Ensino Médio: Enlaces español para jóvenes brasileños (2013) e Cercanía Joven (2013), ambas foram obras selecionadas pelo PNLD 2015.

Uma consideração interessante na pesquisa de Souza (2016) foi a busca por dados a respeito da população negra de cada país hispano-falante. De acordo com a autora, países como Venezuela, Costa Rica, Porto Rico, Colômbia, Cuba, República Dominicana e Guiné Equatorial possuem grande contingente de negras e negros. Outros países como Uruguai, Guatemala, México, Peru, Equador têm uma população negra em contingente menor. A partir disso, a autora elucida que "o espanhol é uma língua também negra, portanto cabe reivindicar que presença linguística, cultural e social tem no LD". O levantamento de dados mostrou que os países que têm maior aparição e ocupam posições de prestígio nas coleções analisadas são Argentina, Espanha e Chile, os que possuem menor proporção de negros.

Em relação à representação de negros e negras em imagens das coleções, a autora contabilizou o número de páginas nas quais constavam: apenas pessoas brancas, pessoas brancas e negras e apenas pessoas negras, em cada livro de cada coleção. Os resultados obtidos pela pesquisadora mostram a seguinte ordem decrescente de frequência: apenas pessoas brancas $>$ pessoas negras e brancas $>$ apenas pessoas negras. Na coleção Cercanía, foi constatado que em $65 \%$ das páginas há apenas pessoas brancas, em 22\% das páginas há pessoas negras e brancas e em 12\% 
das páginas há somente pessoas negras. Na coleção Enlaces, os percentuais foram de: $55 \%$ das páginas apresentam apenas pessoas brancas, $35 \%$ apresentam pessoas negras e brancas e $8 \%$ apresentam apenas pessoas negras.

Em um terceiro momento da análise, Souza (2016) buscou identificar pessoas negras em contexto de protagonismo. Na obra Cercanía foram identificadas representações de pessoas negras em contextos profissionais, afetivos e educacionais, entretanto em poucas oportunidades. A coleção Enlaces apresentou mais oportunidades, mas com pouco aprofundamento nas discussões propostas. Por fim, a autora explica que, ao longo da análise das duas coleções, notou muitas vezes que pessoas negras são retratadas como adereços, sem uma contextualização devida, como ocorre quando as pessoas brancas são representadas.

Outras duas pesquisas que analisaram obras aprovadas pelo PNLD para o Ensino Médio foram a de Ferreira et. al. (2019) e a de Enevan e Jovino (2019), ambas pesquisaram representações de raça, gênero e classe na obra Síntesis (2010).

Ferreira et. al. (2019) analisaram a representação de raça, gênero e classe social em imagens do primeiro volume da coleção Sintesis (2010). As autoras explicam que a motivação para o estudo das representações de raça e gênero nos LD decorre do fato de que nem sempre essas identidades são contempladas, o que gera um distanciamento entre o conteúdo escolar e a realidade dos alunos e afeta na construção de suas identidades.

Assim como Jovino (2014), Ferreira et. al. (2019) também identificaram imagens positivas de representações da identidade negra e desigualdade no número de representações entre negros e brancos, com desvantagens para os negros.

Como imagens positivas, as autoras encontraram: uma imagem de uma mulher africana juntamente com um texto que fala sobre a origem dos seres humanos na África, seguida de uma crônica sobre racismo e seus entraves; uma imagem de uma família negra numerosa, empoderada e feliz; e um homem negro exercendo a profissão de advogado.

Em relação ao número de imagens que representam brancos e negros, Ferreira et. al. (2019) contabilizaram 101 imagens, sendo 73 pessoas brancas e 28 pessoas negras. Como se vê, os negros não chegam a ser representados em $30 \%$ das imagens que constam no livro analisado, o que, segundo as autoras, reafirma a branquitude como norma e exemplifica a divisão racial existente no ambiente escolar e o racismo velado na escola.

Tendo em vista os resultados do estudo, as autoras concluem que as representações visuais em relação à raça (e também a gênero e classe social) no livro de espanhol ainda são precárias. Portanto, é de extrema relevância lançar um olhar para os LD de modo a desconstruir o racismo estrutural institucionalizado e camuflado tanto em políticas educacionais como no interior das instituições.

Enevan e Jovino (2019) analisaram as representações de identidades sociais de gênero, raça e classe em textos e exercícios da coleção Síntesis (2010). Com base nos postulados da Análise de Discurso Crítica, e utilizando a abordagem da sumarização tópica, as autoras selecionaram textos e atividades relacionados a imagens de mulheres negras. Os dados da pesquisa mostraram que, de um total de 525 pessoas representadas em imagens da coleção, apenas 120 são negras. Destas, apenas 40 são mulheres e apenas 5 imagens se relacionam a textos ou exercícios.

Assim como Jovino (2014) e Ferreira et. al. (2019), Enevan e Jovino (2019) também encontraram representações positivas da mulher negra, as quais as autoras denominaram como "tópicos includentes". As imagens exibiam: famílias negras em destaque e mulheres negras ocupando um espaço de poder simbólico; uma mulher negra vinculada a uma proposta de valorização dos modos de viver e se relacionar de diferentes povos; e uma internauta negra que propõe um fórum numa página na internet.

Além disso, as autoras também identificaram que há poucos textos e exercícios relacionados a pessoas negras, e, quando aparecem na coleção, mais da metade dos temas são excludentes, o que não contribui para valorizar e construir identidades negras de maneira positiva.

Com relação aos "tópicos excludentes", foram identificadas representações que correspondiam a estereotipias sobre negros. Segundo as autoras, com base na pesquisa de Martins (2009), os estereótipos clássicos ao representar pessoas negras são: trabalhador braçal, artista, atleta, carente social e africano primitivo. A análise mostrou a presença de dois desses estereótipos na coleção Síntesis: a mulher negra como garçonete (trabalhadora de serviço braçal), sem qualquer problematização dessa representação no exercício relacionado à imagem, e a imagem de uma mulher negra, em sua casa, relacionada a uma atividade de compreensão auditiva na qual apresenta-se um casal que vive em uma favela e afirma gostar de residir nesse lugar, pois as pessoas do local são solidárias (carente social). As autoras ressaltam que essas representações normalizam estereótipos, e a ausência de problematização sobre elas é um modo de invisibilizar a desigualdade social. 
Tendo em vista os resultados dos trabalhos elencados acima, é possível notar que os LD têm exibido representações positivas de negros e indígenas, mas, em termos quantitativos, o número de representações de pessoas brancas ainda é muito maior que o de pessoas de outras raças, o que mostra a necessidade de seguir problematizando e reivindicando espaços e representações positivas das diversidades raciais. Essa é uma tarefa tão necessária quanto urgente, haja vista os efeitos prejudiciais de uma escolarização que acaba por promover desinteresse em alunos que não se veem representados, nem se identificam com o imaginário social apresentado pela escola. Como concluem Silva et al. (2014, p. 43), "ao passo que as mudanças nos livros são tênues, os alunos negros clamam por mudanças com veemência. Portanto, enquanto aguardamos, atuamos (...)"

$\mathrm{Na}$ seção a seguir, são apresentadas as concepções teóricas que orientam a discussão desenvolvida no presente artigo.

\section{PROBLEMATIZANDO IDEOLOGIAS: PRESSUPOSTOS DA ANÁLISE DE DISCURSO CRÍTICA E DE ESTUDOS DECOLONIAIS}

Tendo em vista que a proposta deste estudo é quantificar e qualificar as representações de raça em imagens de LD de Espanhol, através de uma análise discursivo-crítica, faz-se necessário explicitar a concepção de "discurso" com a qual o presente estudo se vincula. "Discurso" é entendido aqui pelos postulados da Análise de Discurso Crítica (ADC), na qual entende-se "Discurso" como o uso da linguagem como forma de prática social, como uma forma de agir sobre o mundo. Assim sendo, os discursos contribuem para construir e/ou transformar realidades sociais.

Norman Fairclough, um dos maiores expoentes da ADC, em sua obra intitulada "Discurso e mudança social" (2016), menciona os efeitos constitutivos do discurso. O autor explica que o discurso contribui para a construção i) de identidades sociais e posições de sujeito; ii) de relações sociais interpessoais; e iii) de sistemas de conhecimento e crenças. Diante disso, os indivíduos, como sujeitos da linguagem que são, estão propensos tanto ao amoldamento ideológico (ou seja, a se conformarem com as formações discursivas/sociais que compõem a sua realidade), como a agir sobre suas práticas discursivas, contestando e reestruturando as formações ideológicas socialmente empreendidas em seus discursos. Nessa perspectiva, a língua é concebida como "uma atividade dialética que molda a sociedade e é moldada por ela" (MELO, 2009 p. 3).

Com base nessas concepções de língua e discurso, a ADC ocupa-se de problematizar os efeitos ideológicos dos discursos que circulam na sociedade. A este respeito, Vieira e Resende (2016, p. 22), com base em Wodak (2004), explicam que "a ADC define-se pela motivação de 'investigar criticamente como a desigualdade social é expressa, sinalizada, constituída, legitimada pelo uso do discurso'.". Assim sendo, ao analista crítico do discurso lhe interessa evidenciar as relações entre a linguagem e certas práticas sociais vistas como naturais, sobretudo aquelas que reverberam desigualdades sociais.

O objeto de investigação do analista do discurso é o texto, em qualquer modalidade: escrito, oral, visual. Neste trabalho, os textos analisados são visuais, não-verbais, já que a análise se centra em imagens nas quais atores sociais de diferentes raças são representados.

No que diz respeito à concepção de imagem como texto, Kress e Van Leeuwen (2006, p. 2) propõem uma Gramática Visual, baseados no entendimento de que

o que na linguagem é expresso por diferentes classes de palavras e estruturas das orações, pode, na comunicação visual, ser expresso pela escolha de diferentes cores ou pelas diferentes estruturas composicionais. Isso tudo afetará o sentido.

Dessa maneira, assim como as escolhas linguísticas verbais, em discursos orais ou escritos, não são aleatórias, pois atendem às necessidades comunicativas dos participantes, a escolha de imagens tampouco o é, o que implica escolhas intencionais e, portanto, ideológicas. Assim sendo, é preciso decodificar, problematizar a linguagem visual, buscando desvelar sentidos que operam a favor de interesses específicos e colaboram para perpetuação de desigualdades sociais.

Conforme mencionado, as imagens analisadas são textos que compõem quatro coleções de LD de Espanhol para o Ensino Fundamental. Sendo assim, os LD são os suportes nos quais os textos imagéticos se encontram e são o meio pelo qual esses textos são consumidos. Nesse sentido, é preciso sublinhar o papel desempenhado pelos LD no processo de escolarização. Conforme explica Oliveira (2008), os LD representam os marcos regulatórios 
pedagógicos nacionais, e expressam os valores imbuídos na sociedade, funcionando como um instrumento a serviço da criação e reprodução de ideologias institucionais e/ou pessoais. Da mesma maneira, Jovino (2014) explica que os LD são materiais que orientam práticas pedagógicas na sala de aula. Além disso, o contato com o livro e com as informações reportadas nele são de extrema relevância para a propagação e a construção de valores, discursos e imagens, funcionando, dessa forma, como uma ferramenta que pode contribuir para romper paradigmas ou manter estereótipos e estigmas.

Teun A. van Dijk postula a existência de três elites simbólicas que têm o poder de controlar a informação, são elas: o discurso midiático, o discurso político e o discurso escolar. Desde os anos 80, os trabalhos de van Dijk vêm focalizando a relação entre discurso e racismo, e, no que diz respeito ao discurso da educação, van Dijk (2008) afirma que este, além do discurso político e midiático, é o mais influente, ideologicamente, na sociedade. O autor ressalta a importância de analisar as estruturas e as estratégias de gêneros do discurso pedagógico, como currículos, livros didáticos, aulas etc, pois dessa forma é possível descrever e explicar como esses discursos contribuem para a reprodução do racismo. van Dijk (2008, p. 21) alerta ainda sobre a autoridade do discurso pedagógico, já que, mais do que qualquer outro discurso, este "define a ideologia oficial e dominante, estabelecendo o conhecimento e a opinião oficial, sem dar lugar a debate ou controvérsia.". Cumpre ressaltar que é através do discurso escolar, nas aulas de língua estrangeira e nos LD que, muitas vezes, as crianças têm acesso e tomam conhecimento sobre povos de outras partes do mundo, sobre imigração, imigrantes, negros, indígenas etc. Segundo van Dijk, essas informações são quase sempre sucintas e tendenciosas.

Isto posto, vale salientar a gravidade de que os LD possam vir a contribuir, de alguma maneira, para a reprodução de práticas discursivas discriminatórias, haja vista o espaço ocupado por este artefato no processo de escolarização. Assim sendo, problematizar a representação racial no contexto escolar consiste numa ação importante para evidenciar e desnaturalizar percepções social e historicamente enraizadas, como as pré-concepções relacionadas às raças.

No que diz respeito a concepções sobre raça, Maldonado-Torres (2007 apud VIEIRA, 2019, p. 89) coloca a ideia de raça no cerne do conceito de colonialidade. Para este autor, colonialidade diz respeito "à forma como o trabalho, o conhecimento, a autoridade e as relações inter-subjetivas se articulam através do mercado capitalista mundial e da ideia de raça, sobre três bases principais": a colonialidade do poder, do saber e do ser.

Resende (2019, p. 21) esclarece que a colonialidade é um efeito do colonialismo e "se reproduz em livros, em escolas e universidades, nos padrões culturais e estéticos, no senso-comum". Considerando que, na base epistemológica da ADC, está a compreensão de Discurso como prática social, como elemento que molda a sociedade e, ao mesmo tempo, é moldado por ela, numa relação dialética, é importante destacar o foco na expectativa de mudança social. Desse modo, como forma de luta contra hegemônica do discurso colonial, existe o decolonial, aquele que vem questionar, problematizar, intervir, com vistas a propor construções alternativas (cf. RESENDE, 2019). Nesse sentido, Vieira (2019, p. 111) menciona a importância dos estudos críticos do discurso no processo de decolonização do saber, do poder e do ser. Essa autora explica que a contribuição desse campo se dá ao

mapear e sistematizar representações (formas de saber), organizadas e distribuídas nas ações-interações sociais (formas de poder), que podem contribuir para processos de identificação (formas de ser) mais conscientes das práticas, valores e crenças que sustentam estruturas opressoras (...).

Considerando a proposta deste estudo, pode-se dizer que este vem a ser uma contribuição (acadêmica) para práticas decoloniais, uma vez que, ao questionar e problematizar as representações de raça e de atores sociais (âmbito do saber) no discurso veiculado em LD através de suas imagens (âmbito do poder), busca-se sensibilizar os leitores para certas formas de identificar e de representar (âmbito do ser) que evidenciam (ou deixam velados) olhares condicionados pelo racismo.

Na seção a seguir, busca-se delimitar a conjuntura social de produção, alcance e consumo dos textos analisados. Assim, são apresentadas as obras, os autores e as editoras que as produziram e comercializaram. Além disso, são brevemente descritas as análises realizadas e as categorias analíticas.

\section{AS OBRAS ANALISADAS E AS CATEGORIAS DE ANÁLISE}

A maioria dos estudos que discutem conteúdos de LD analisam obras aprovadas pelo PNLD e, muitas vezes, salientam aspectos divergentes entre o que se propõe nos editais e o que os resultados de suas análises mostram acerca 
dos conteúdos dos livros. Certamente, a preferência por obras aprovadas pelo PNLD decorre de uma preocupação dos pesquisadores para com o fato de que são livros indicados para serem adotados em todas as escolas públicas do Brasil, o que significa que seus conteúdos serão disseminados a muitos estudantes.

Neste artigo, entretanto, nenhuma das coleções analisadas foi submetida ao PNLD, apenas a coleção Saludos foi avaliada e aprovada pelo referido programa alguns anos depois (2011). As coleções analisadas foram doadas à autora do presente artigo por professores de Espanhol que já haviam utilizado os livros para ensino dessa língua em diferentes escolas das redes pública e privada de Florianópolis. Portanto, independente de terem passado por um processo seletivo mais rigoroso, as obras escolhidas já foram/são adotadas pelas escolas e, por consequência, seus conteúdos já foram/são consumidos por diversos professores e alunos.

Além disso, outra questão que motivou a análise de obras que não passaram pelo PNLD advém do relato de uma professora que doou uma das coleções analisadas aqui. Segundo essa professora, ao solicitar que fosse adotada uma outra coleção de LD de Espanhol, tendo em vista que a abordagem da coleção que se utilizava até então lhe parecia muito estruturalista, a coordenação da escola concordou com seu pedido, mas lhe advertiu que não escolhesse "livro de escola pública", referindo-se às coleções aprovadas pelo PNLD. Tal relato mostra que, em determinados contextos de ensino, as obras a serem adotadas serão, preferencialmente ou até mesmo obrigatoriamente, as que não tiverem passado por uma análise mais criteriosa em relação aos conteúdos veiculados, como é o caso dos livros aprovados pelo PNLD, os quais, ainda assim, apresentam problemas diversos, conforme apontado por muitos estudos que já os analisaram.

As coleções analisadas neste estudo remontam o período de mais de uma década, com o objetivo de observar que avanços podem ter ocorrido e que aspectos ainda se conservam no que diz respeito à representação de raças nos LD de Espanhol ao longo do tempo. As coleções analisadas são:iAdelante! (2002), Saludos (2008), Ventana al español (2011) e Contraseña (2015). Todas se destinam ao ensino de Espanhol como língua estrangeira para o Ensino Fundamental, e todas possuem quatro volumes, sendo um para cada série escolar: sexto, sétimo, oitavo e nono anos. Os exemplares analisados são manuais do professor, os quais contém, além de todo o conteúdo igual ao que está no livro do aluno, as respostas das atividades e algumas orientações para o professor.

Com relação à produção e comercialização das obras, a coleção iAdelante! foi produzida pela editora espanhola SM. Segundo informação disponível na primeira página do livro, esta seria uma das editoras líderes na publicação de livros didáticos. A coleção teve seus direitos comprados e comercializados no Brasil pela editora FTD, uma empresa com longos anos de atuação no mercado editorial, já que foi fundada em 1902. A coleção Saludos foi produzida e comercializada pela editora Ática, outra editora também muito reconhecida no setor de livros escolares no Brasil, com mais de 2300 títulos em seus catálogos, conforme informação disponível na página virtual da editora. As coleções Ventana al español e Contraseña foram produzidas e comercializadas pela editora Moderna/Santillana, que é de origem brasileira, mas foi comprada e passou a ser administrada, em 2001, pelo grupo editorial espanhol Prisa, conglomerado empresarial que controla também o jornal El País, uma das mídias de massa da Espanha.

Conforme se pode notar, as instituições produtoras e comercializadoras dos materiais escolhidos para análise são grandes empresas no setor de livros escolares e, certamente, com expressivo poder de alcance, o que significa que o consumo dos textos analisados tende a ser grande.

No que diz respeito à autoria, à exceção da coleção Saludos, as demais coleções apresentam apenas os nomes dos autores nas capas, contracapas e fichas catalográficas, sem maiores informações sobre os autores.

A coleção iAdelante! tem duas autorias. Os livros para o $5^{\circ}$ e $6^{\circ}$ anos são de autoria de Virgilio Borobio e os livros para o $7^{\circ}$ e $8^{\circ}$ anos são de Belén Artuñedo e Cynthia Donson. Em buscas pela internet, tampouco se encontram informações sobre o primeiro autor, os resultados remetem apenas a obras dele e a páginas de editoras. Quanto às autoras, foi possível identificar que Belén Artuñedo é professora do Departamento de Filologia Francesa e Alemã da Universidad de Valladolid, na Espanha, e que é graduada em Letras Modernas e suas literaturas e licenciada em Francês e Alemão. Sobre Cynthia Donson, ocorre o mesmo que nas buscas por informações de Virgilio Borobio.

A coleção Saludos, de Ivan Martin, apresenta na contracapa dos livros a informação de que o autor é doutor em Letras pela Universidade de São Paulo e professor da Pontifícia Universidade Católica de São Paulo. Em seu currículo Lattes consta que ele é graduado em Letras Português-Espanhol pela Universidade de São Paulo.

As autoras da coleção Ventana al español são Adriana Pedro de Almeida e Roberta Amendola. Sobre a primeira autora, segundo informações que se encontram na internet, é uma profissional da área de edição de materiais didáticos voltados para o ensino das línguas inglesa e espanhola. Em seu currículo Lattes, cuja última atualização é de 
2004, encontra-se apenas a informação de que a autora iniciou, em 2002, a graduação em Letras Português-Espanhol na Universidade de São Paulo. Sobre Roberta Amendola, em seu currículo Lattes, consta a informação de que é mestra em Educação pela Universidade de São Paulo, onde também cursou o bacharelado e a licenciatura em Letras Português-Espanhol. Além disso, possui experiência na área de autoria, edição, tradução e revisão de livros didáticos para Ensino Fundamental e Médio.

A coleção Contraseña é de autoria de Marília Vasques Callegari e Simone Rinaldi, ambas são bacharéis e licenciadas em Letras-Espanhol, mestras e doutoras em Educação pela Universidade de São Paulo.

As buscas por informações sobre os autores das coleções em questão mostram que (quase) todos são profissionais da área de ensino de línguas, com formação superior e com experiência na produção de materiais didáticos para o ensino de idiomas.

As (breves) descrições sobre as editoras e os autores são relevantes para que se tenha uma noção a respeito de quem fala, de onde fala e qual o provável alcance de desses LD.

Quanto à análise realizada, procedeu-se a duas etapas. Primeiramente, foi feito um levantamento quantitativo, a fim de verificar a frequência com que pessoas negras, indígenas, asiáticas e brancas ${ }^{1}$ são contempladas em imagens presentes nos livros em questão. A contagem foi realizada manualmente e considerou a quantidade de imagens em que aparecem pessoas de cada raça mencionada.

Em segundo lugar, foi realizada uma apreciação qualitativa/interpretativa em relação ao modo como os atores sociais de cada raça são representados e os papéis sociais que lhes são atribuídos nas imagens das quatro coleções analisadas. Para isso, são consideradas as categorizações propostas por van Leeuwen (2008), no capítulo "A representação visual de atores sociais". Tais categorizações foram adaptadas pelo autor a partir de categorizações criadas para analisar representações de atores sociais em textos verbais (escritos e orais). Para a análise de imagens, van Leeuwen parte de duas questões: i) como as pessoas são retratadas? e ii) como as pessoas retratadas se relacionam com o espectador (leitor)? Neste estudo, serão consideradas apenas as categorizações estabelecidas para responder à primeira questão. Quais sejam:

\section{Exclusão}

Categorizações Inclusão $\left\{\begin{array}{l}\text { Envolvido na ação }\left\{\begin{array}{l}\text { Agente } \\ \text { Paciente }\end{array}\right. \\ \left\{\begin{array}{l}\text { Genérico }\left\{\begin{array}{l}\text { Categorização cultural } \\ \text { Categorização biológica }\end{array}\right. \\ \text { Específico }\end{array}\right. \\ \left\{\begin{array}{l}\text { Individual } \\ \text { Grupo }\left\{\begin{array}{l}\text { Homogeneização } \\ \text { Diferenciação }\end{array}\right.\end{array}\right.\end{array}\right.$

Figura 1. Categorização dos atores sociais, segundo van Leeuwen (2008, p. 147)

De acordo com essas classificações, atores sociais podem ser excluídos dos textos: quando não há representação de pessoas em todos os contextos em que, na realidade, elas estão presentes; incluídos nos textos:

\footnotetext{
1. Ainda que essa classificação das raças possa ser generalista e simplificadora, e misture critérios (cor de pele, etnia e localização geográfica), optou-se por essas denominações por considerar que, com os termos "negras", "indígenas", "asiáticas" e "brancas", o leitor remete mais facilmente aos traços fenotípicos que caracterizariam pessoas de cada raça. Como os textos analisados são imagens, a identificação de raça se dá apenas pelo visual e, sendo assim, apenas traços físicos estão sendo considerados.
} 
envolvidos em alguma ação ou não. Se executam uma ação, são agentes. Se estão envolvidos em uma ação, mas têm sua agência encoberta, figurando como pessoa sobre a qual uma ação é realizada, são pacientes. Também podem ser representados de maneira específica, ou de maneira genérica por categorização cultural: marcada através de atributos como vestimentas e penteados; e por categorização biológica: com destaque para características físicas, as quais podem conotar associações positivas ou negativas. Podem ser apresentados individualmente ou em grupo. Neste último caso, podem figurar de forma diferenciada ou de forma homogeneizada, parecendo que todos os membros de um grupo são iguais.

É importante considerar que as maneiras como atores sociais são representados em textos se relaciona diretamente a discursos particulares e, por consequência, podem ter implicações ideológicas (cf. VIEIRA e RESENDE, 2016).

Sob essas concepções, busca-se analisar as representações de atores sociais nas coleções de LD mencionadas, identificando, sobretudo, formas de representar que reforçam preconceitos, naturalizam estereótipos e, por consequência, contribuem simbolicamente para manter desigualdades sociais entre indivíduos de diferentes raças. Para isso, a análise empreendida neste estudo considera todas as categorizações expostas acima.

Na próxima seção, apresentam-se os resultados das análises realizadas e discussões acerca dos dados.

\section{REPRESENTAÇÕES DE ATORES SOCIAIS DE DIFERENTES RAÇAS NOS LD DE ESPANHOL: O QUE (NÃO) MUDOU EM MAIS DE UMA DÉCADA?}

Apresentam-se a seguir os resultados das análises realizadas em cada coleção. Primeiramente, serão apresentados os dados quantitativos, com o objetivo de evidenciar a frequência com que pessoas negras, indígenas, asiáticas e brancas são representadas nas imagens de cada livro das quatro coleções selecionadas para análise. Na sequência, serão apresentados os dados qualitativos, os quais compreendem: os papéis sociais desempenhados por atores sociais de cada raça e como esses atores são representados, em cada coleção, com base nas categorizações de van Leeuwen (2008).

Na coleção iAdelante! (2002), o número de imagens que contém atores sociais de cada raça é o seguinte:

Tabela 1. Número de imagens que contém pessoas de cada raça na coleção ¡Adelante!

\begin{tabular}{|c|c|c|c|c|c|}
\hline Atores sociais & Livro 1 & Livro 2 & Livro 3 & Livro 4 & Total de cada raça \\
\hline Negros & 4 & 6 & 7 & 1 & $18(6 \%)$ \\
\hline Indígenas & 1 & - & 1 & - & $2(0,6 \%)$ \\
\hline Asiáticos & - & 1 & - & 1 & $2(0,6 \%)$ \\
\hline Brancos & 86 & 96 & 61 & 40 & $283(93 \%)$ \\
\hline $\mathrm{N}^{0}$ total de imagens & 91 & 103 & 69 & 42 & $305(100 \%)$ \\
\hline
\end{tabular}

Conforme os dados exibidos na Tabela 1, a quantidade de imagens em que pessoas negras são representadas corresponde a $6 \%$ do total de imagens de toda a coleção. Pessoas indígenas e asiáticas estão em menos de $1 \%$ das imagens, sendo, inclusive, completamente excluídas em alguns livros. Por outro lado, as pessoas brancas estão representadas em $93 \%$ das imagens, o que mostra um percentual de representatividade esmagador em comparação com as demais raças analisadas. Por estes resultados, é possível concluir que, dentre as categorizações mais gerais propostas por van Leeuwen (2008) (incluídos, excluídos), as pessoas negras, indígenas e asiáticas estão praticamente excluídas da coleção iAdelante!, estando incluídas majoritariamente apenas as pessoas brancas.

Em relação aos papéis sociais desempenhados por atores sociais de cada raça, os resultados foram os seguintes:

- pessoas negras são representadas como: taxista, aluno, convidado em festa, dançarina de carnaval, em situação de miséria, jogador de futebol, tenista, presidente (Mandela), pedinte, imagens só do rosto.

- Pessoas indígenas são representadas como: operador de caixa de mercado, imagem só do rosto.

- Pessoas asiáticas são representadas como: aluno, imagem só do rosto.

- Pessoas brancas são representadas como: alunos, professora, tenista, rei, atriz, cantor, piloto de F1, garçom, secretária, atendente, jornalista, engenheira, editor, músico, diretor de cinema, bombeiro, pintor, veterinária, 
médico, enfermeira, arquiteto, aeromoça, fotógrafo, cabeleireira, vidente, cientista, pintor, escritor, técnico de informática, militar, açougueiro.

Os papéis sociais designados para pessoas negras indicam representações de subalternidade (em situação de miséria, pedinte), estereotipia (dançarina de carnaval, jogador de futebol) e atividades de pouco prestígio (taxista, convidado de festa), havendo apenas duas representações (tenista e presidente) de maior prestígio social.

Das poucas pessoas indígenas e asiáticas representadas na coleção, em metade das representações não é possível caracterizar um papel social, pois só aparecem os seus rostos nas imagens. Na única representação identificável como papel social, a pessoa indígena é retratada exercendo uma profissão socialmente desvalorizada (operador de caixa de supermercado) e a pessoa asiática, representada como aluno, tem uma representação socialmente positiva, embora seja apenas uma única aparição.

Além da presença majoritária nas imagens, as pessoas brancas também são representadas em uma grande diversidade de papéis sociais, exercendo tanto atividades socialmente prestigiadas (tenista, rei, atriz, cantor, piloto de F1, diretor de cinema, médico, cientista, escritor) como de menor reconhecimento social (garçom, secretária, atendente, cabeleireira, vidente, açougueiro), além de atividades relacionadas à formação intelectual (aluno, professora, editor, cientista, escritor), indicando uma prevalência por todos os setores da sociedade que são representados nos livros. Diferentemente dos demais atores representados, é sempre possível identificar algum papel social nas pessoas brancas das imagens, não havendo imagens que exibam apenas o rosto de uma pessoa.

Seguem algumas imagens da coleção iAdelante!.

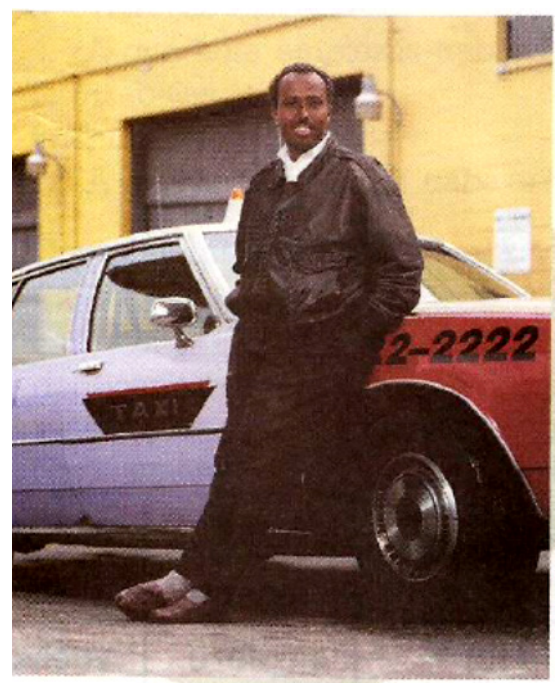

Felipe - taxista

Figura 2. Representação de pessoa negra: taxista (livro 1, p. 97)

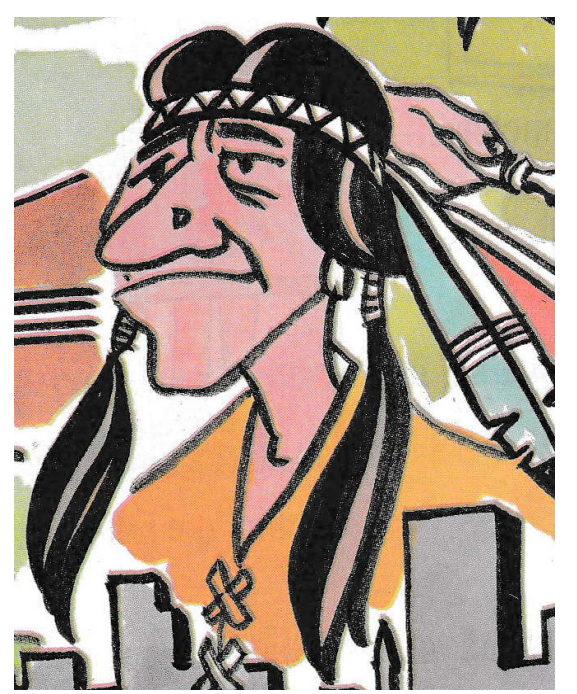

Figura 3. Representação de indígena: imagem só do rosto (livro 3, p. 26) 


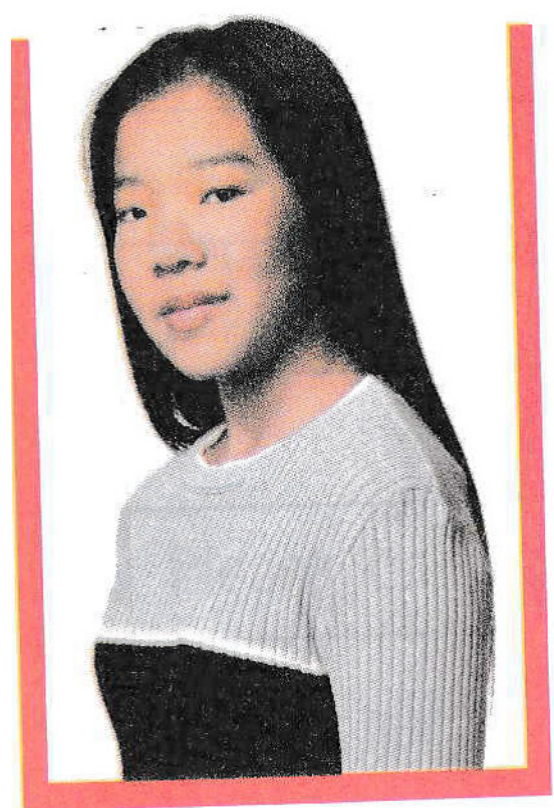

Figura 4. Representação de pessoa asiática: imagem só do rosto (livro 2, p. 139)

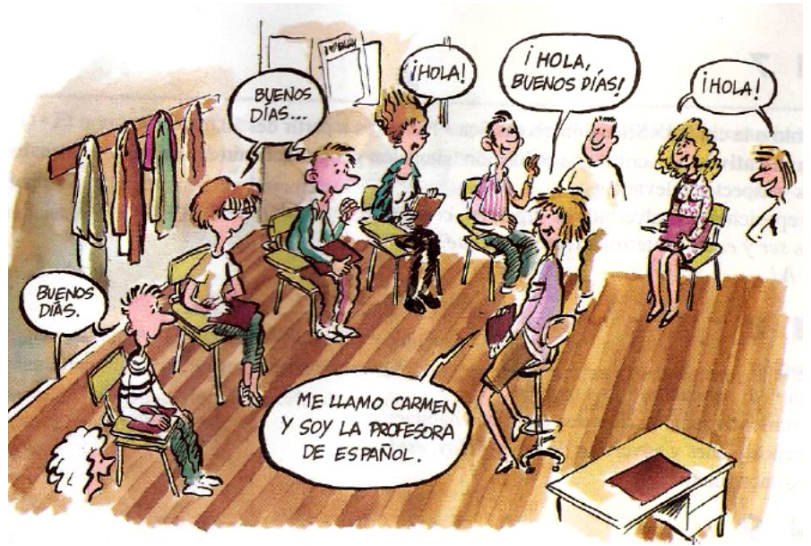

Figura 5. Representação de pessoas brancas: professora e alunos (livro 1, p. 6)

Na coleção Saludos (2008), a quantidade de imagens que apresenta atores sociais de cada raça analisada é a seguinte:

Tabela 2. Número de imagens que contém pessoas de cada raça na coleção Saludos

\begin{tabular}{|c|c|c|c|c|c|}
\hline Atores sociais & Livro 1 & Livro 2 & Livro 3 & Livro 4 & Total de cada raça \\
\hline Negros & 21 & 7 & 11 & 15 & $54(17 \%)$ \\
\hline Indígenas & 5 & - & 2 & 10 & $17(6 \%)$ \\
\hline Asiáticos & 4 & 4 & 1 & 1 & $10(3 \%)$ \\
\hline Brancos & 62 & 40 & 78 & 51 & $231(74 \%)$ \\
\hline $\mathrm{N}^{0}$ total de imagens & 92 & 51 & 92 & 77 & $312(100 \%)$ \\
\hline
\end{tabular}

De acordo com os dados exibidos na Tabela 2, os percentuais de representação de cada raça na coleção Saludos mostram comportamento semelhante aos da coleção iAdelante!, uma vez que pessoas brancas são representadas em um número muito superior de imagens (74\%) em comparação com negros (17\%), indígenas (6\%) e asiáticos (3\%). Em relação à coleção iAdelante!, produzida e comercializada seis anos antes da coleção Saludos, nota-se um aumento nos percentuais de imagens exibindo pessoas negras, indígenas e asiáticas, o qual pode parecer significativo, pois corresponderia a mais que o dobro da primeira para a segunda coleção analisada. Porém, esse aumento ainda dista de 
ser expressivo, pois não chega nem perto da frequência com que pessoas brancas são representadas, nem mesmo se as quantidades de imagens dos sub representados fossem somadas.

Em relação aos papéis sociais desempenhados por atores sociais de cada raça, as análises mostraram que:

- pessoas negras são representadas como: de terno no escritório, no computador, imagem só do rosto, atriz, aluno, jogador de basquete, jogador de futebol, praticando atletismo, brincando de amarelinha, lanchando com amigos, na piscina.

- Pessoas indígenas são representadas como: entrevistado, estudante, vendedora de flores, em festas folclóricas, imagem só do rosto.

- Pessoas asiáticas são representadas como: alunas, imagem só do rosto.

- Pessoas brancas são representadas como: em festa de aniversário, padeiro, professor, aluno, empresário, no computador, fada, princesa, cantor(a), ator, atriz, jornalista, jogando basquete, jogando futebol, vendo TV, cozinheiro, garçom, encanador, veterinária, feirante.

Assim como a análise quantitativa, a análise qualitativa da coleção Saludos também apresenta resultados semelhantes aos obtidos sobre a coleção iAdelante!. Em ambas as coleções, as pessoas asiáticas são representadas da mesma forma: como alunos(as) e com imagem só do rosto, o que não permite atribuir-lhes um papel social. As pessoas indígenas são representadas de forma um pouco mais diversificada. Entretanto, há representações que constituem estereotipia (em festas folclóricas), atividade socialmente desvalorizada (vendedora de flores) e sem papel social identificável (imagem só do rosto). Apenas duas representações poderiam ser consideradas socialmente positivas sobre indígenas: a de entrevistado e a de estudante.

As pessoas negras também são retratadas em mais papéis sociais do que na coleção anteriormente analisada. Há representações que podem ser vistas como socialmente positivas e/ou valorizadas, como: de terno no escritório, no computador, atriz, aluno, brincando de amarelinha, lanchando com amigos, na piscina. Mas também há imagens nas quais não é possível atribuir um papel social, pois só mostram os rostos das pessoas, e representações do estereótipo "negros são talentosos para esportes", em imagens que os exibem como: jogador de basquete, jogador de futebol, praticando atletismo. Em relação à representação de pessoas brancas, a análise de Saludos também se assemelha a de iAdelante!: as pessoas brancas são representadas em diversos papéis sociais, atuando tanto em atividades de pouca (padeiro, cozinheiro, garçom, encanador, feirante) como de maior valorização social (professor, aluno, empresário, no computador, fada, princesa, cantor(a), ator, atriz, jornalista, jogando basquete, jogando futebol, vendo TV, veterinária).

Abaixo, destacam-se algumas imagens presentes na coleção Saludos.

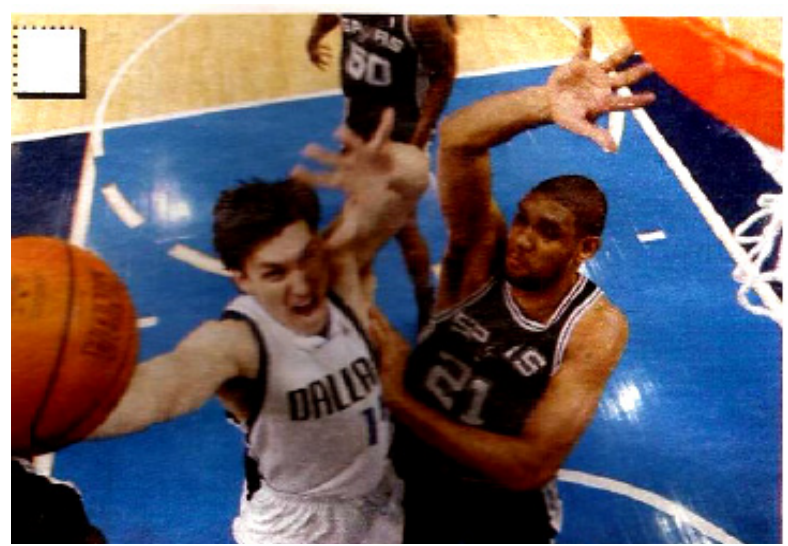

Figura 6. Representação de pessoa branca e pessoa negra: jogadores de basquete (livro 1, p. 128) 


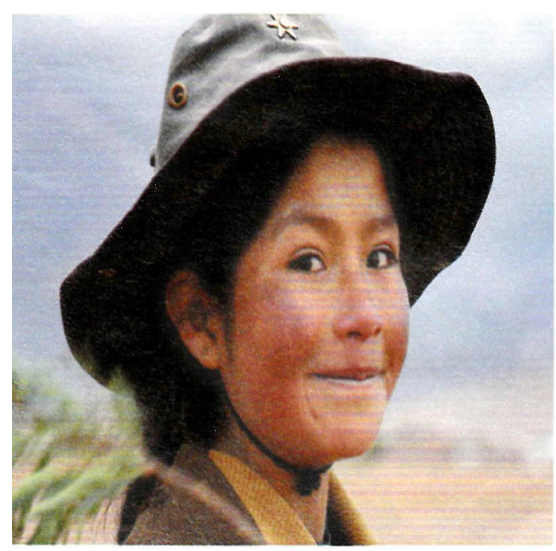

Figura 7. Representação de pessoa indígena: imagem só do rosto (livro 1, p. 37)

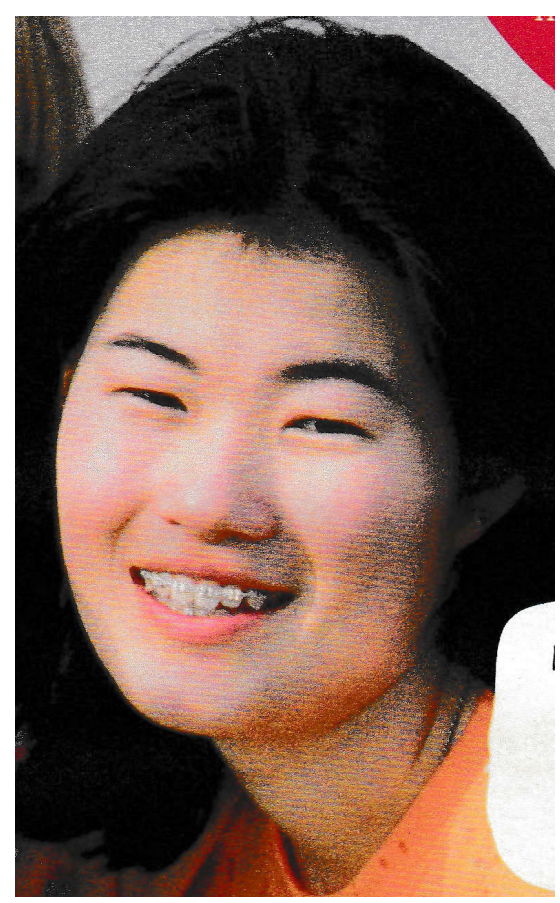

Figura 8. Representação de pessoa asiática: imagem só do rosto (livro 1, p. 23)

A coleção Ventana al español (2011) apresenta as seguintes quantidades de imagens com atores sociais de cada raça analisada:

Tabela 3. Número de imagens que contém pessoas de cada raça na coleção Ventana

\begin{tabular}{|c|c|c|c|c|c|}
\hline Atores sociais & Livro 1 & Livro 2 & Livro 3 & Livro 4 & Total de cada raça \\
\hline Negros & 22 & 14 & 1 & 2 & $39(11 \%)$ \\
\hline Indígenas & - & - & - & - & $0(0 \%)$ \\
\hline Asiáticos & 8 & 7 & - & 2 & $17(5 \%)$ \\
\hline Brancos & 93 & 89 & 47 & 55 & $284(84 \%)$ \\
\hline $\mathrm{N}^{\circ}$ total de imagens & 123 & 110 & 48 & 59 & $340(100 \%)$ \\
\hline
\end{tabular}

Nessa coleção, os dados quantitativos também se assemelham aos das duas primeiras coleções analisadas (brancos em representação majoritária $(84 \%)$; negros $(11 \%)$ e asiáticos $(5 \%)$ com pouquíssimas aparições nos livros), mas com constatações ainda piores: nenhuma representação de pessoas indígenas em toda a coleção. Pessoas negras e asiáticas, embora sejam contempladas na coleção, também são excluídas nos livros 3 e 4, com nenhuma ou pouquíssima representação. Apenas as pessoas brancas são representadas nas imagens de todos os livros da coleção, e sempre em grande quantidade (nos livros 3 e 4 correspondem a quase 100\%). 
Sobre os papéis sociais desempenhados por atores sociais de cada raça, os resultados foram os seguintes:

- Pessoas negras são representadas como: praticando esportes, alunos, mãe e filho, tia, em centro de acolhimento, em situação de miséria, família, africanos em festa, grafiteiro, imagem só do rosto.

- Pessoas asiáticas são representadas como: aluno, em família, mãe, artista de teatro, no telefone.

- Pessoas brancas são representadas como: estudante, professora, em família, empresário, palhaço, policial, arquiteto, recepcionista, cozinheiro, escritora, pintor, jornalista, contadora, tradutor, engenheiro, desenhista, nadador, ginasta, tenista, garçom, artista, câmera man, farmacêutico, atendente, juiz, eleitor, médica.

Mais uma vez os papéis sociais atribuídos a representantes de cada raça se assemelham entre as coleções. As pessoas negras são representadas em núcleos familiares, o que ainda não havia aparecido nas análises das coleções anteriores. Entretanto, nota-se mais uma vez uma prevalência de representações estereotipadas: pessoas negras praticando esportes, em centro de acolhimento, em situação de miséria, africanos em festa, grafiteiro. Além disso, as imagens que não permitem identificar o papel social das pessoas representadas ainda persistem (imagem só do rosto). O mesmo se nota para a representação de pessoas asiáticas: também são representadas em núcleos familiares e também continuam a ser representadas como aluno. Assim como nas demais coleções analisadas, as pessoas brancas são representadas desempenhando uma série de papéis sociais, a maioria deles socialmente valorizados.

Seguem algumas imagens da coleção Ventana al Español.

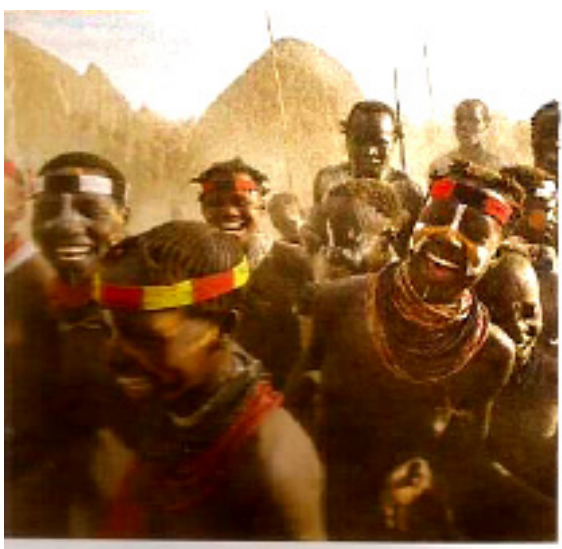

Figura 9. Representação de pessoas negras: africanos em festa (livro 3, p. 96)

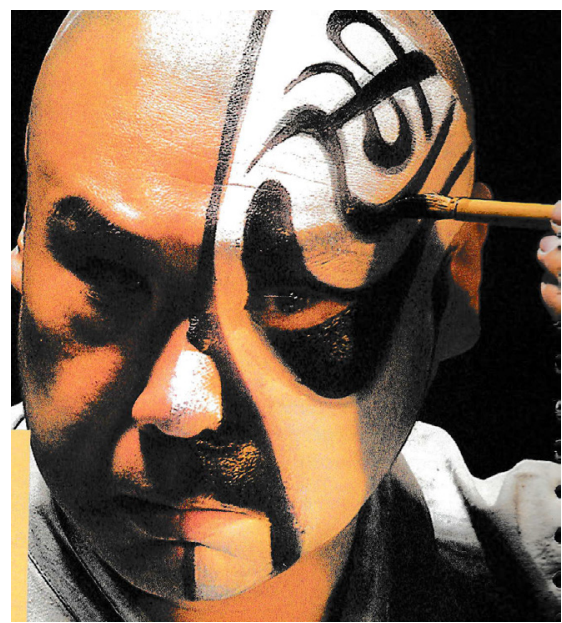

Figura 10. Representação de pessoa asiática: artista de teatro (livro 4, p. 30) 


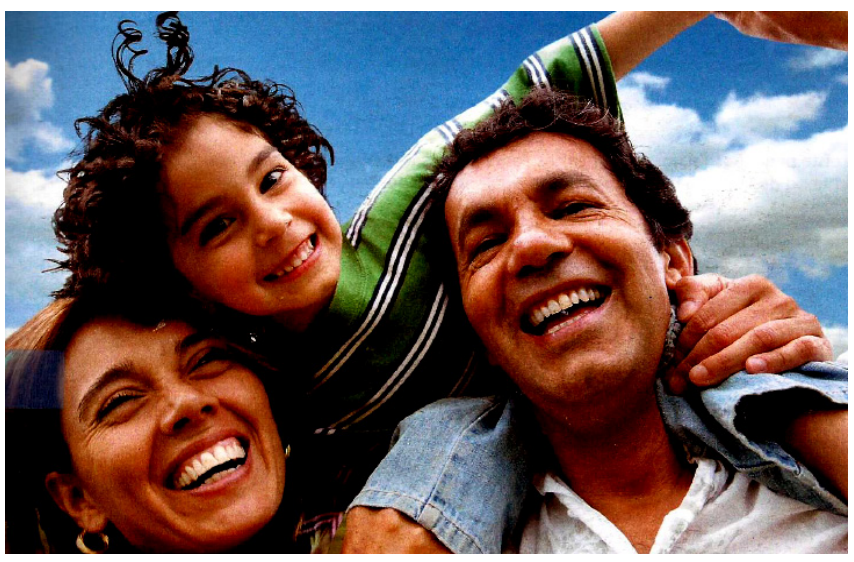

Figura 11. Representação de pessoas brancas: em família (livro 1, p. 86)

Nesta coleção, duas imagens, uma no livro 1 e outra no livro 4, chamam atenção pelo caráter explicitamente racista. Na página 96 do livro 1, retrata-se uma fila de pessoas africanas miseráveis, dentre as quais a maioria é criança. Essa imagem acompanha o poema "Niños de Somalia", da escritora espanhola Gloria Fuentes. O poema é a conjugação do verbo "comer", em espanhol, com uma alteração na última pessoa gramatical ("yo como, tú comes, él come, nosotros comemos, vosotros coméis, iellos no!"). Esses textos (poema e imagem) são seguidos de duas questões de compreensão textual, uma delas pergunta ao aluno o que há de diferente na conjugação do verbo "comer" e a outra pergunta como se conjuga o verbo "comer" na terceira pessoa do plural. O livro não apresenta nenhuma problematização e nem sequer alguma sugestão de discussão sobre a questão social exibida nos textos. Na Figura 12, pode-se ver a imagem em comento.

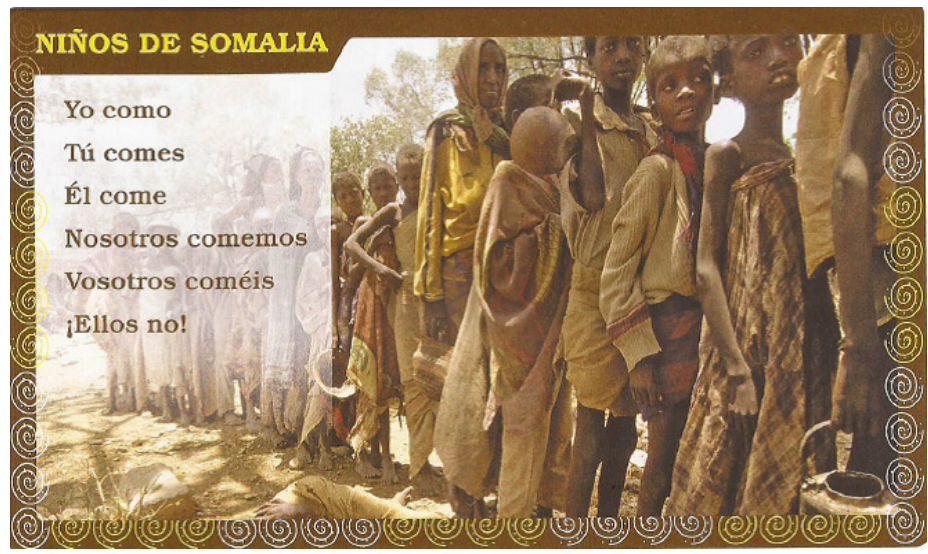

Figura 12. Representação de pessoas negras: africanos miseráveis (livro 1, p. 96)

Da mesma forma, na página 13 do livro 4, encontram-se três imagens que retratam: uma moça branca sorridente, um rapaz com olhar sereno e um violão em mãos e uma moça negra pensativa. A atividade trata da expressão de desejos, exemplificando uma das funções comunicativas em que se usa o presente do subjuntivo. A moça branca diz que seu sonho é conhecer o cantor Juan Luis Guerra, o rapaz diz que deseja tocar com Carlos Santana e a moça negra diz que espera que façam um show para combater a pobreza no mundo. Como se pode notar, o livro vincula preocupação com a pobreza à pessoa negra, como se pode ver na Figura 13 abaixo. 


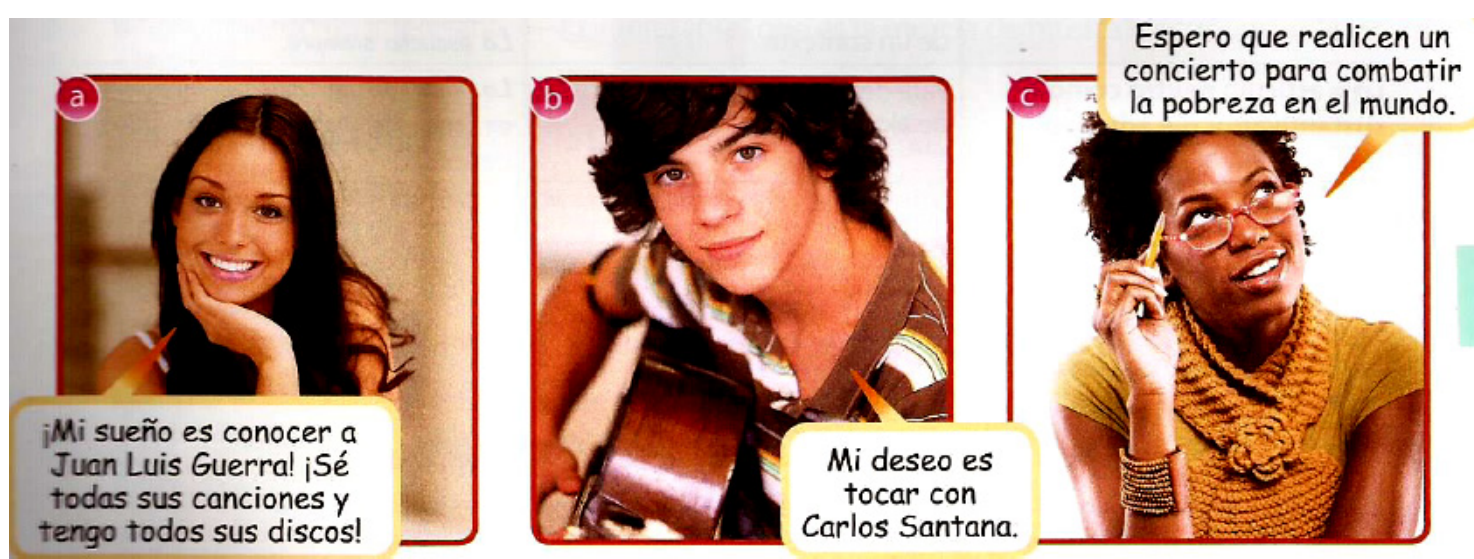

Figura 13. Representação de pessoas brancas e pessoa negra (livro 4, p. 13)

A exibição dessas imagens e a forma como são abordadas nos livros mostram a omissão e o descaso do material para com questões raciais graves, contribuindo para a naturalizar preconceitos e estereótipos negativos contra pessoas negras.

Na última coleção analisada, Contraseña (2015), os resultados da análise sobre o número de imagens que retratam cada raça foram:

Tabela 4. Número de imagens que contém pessoas de cada raça na coleção Contraseña

\begin{tabular}{|c|c|c|c|c|c|}
\hline Atores sociais & Livro 1 & Livro 2 & Livro 3 & Livro 4 & Total de cada raça \\
\hline Negros & 32 & 18 & 11 & 12 & $73(15 \%)$ \\
\hline Indígenas & 5 & 2 & 3 & - & $10(2 \%)$ \\
\hline Asiáticos & 9 & 3 & 3 & - & $15(3 \%)$ \\
\hline Brancos & 122 & 93 & 86 & 96 & $397(80 \%)$ \\
\hline N $^{\text {o }}$ total de imagens & 168 & 116 & 103 & 108 & $495(100 \%)$ \\
\hline
\end{tabular}

Os percentuais de imagens que representam pessoas de cada raça se mantêm muito parecidos com os das coleções anteriores: o número de imagens representando pessoas negras (15\%), indígenas (2\%) e asiáticas (3\%) é muito inferior ao número de imagens representando pessoas brancas (80\%), mostrando, mais uma vez, uma prevalência de representação dessa última raça sobre todas as demais. No livro 4, as representações de indígenas e asiáticos, que já era ínfima nos demais livros, chega a zero, ou seja, há exclusão total dessas raças.

Em relação aos papéis sociais designados a atores sociais de cada raça, identificou-se que:

- Pessoas negras são representadas como: estudante, aeromoça, policial, enfermeiro, advogada, paciente, repórter, estilista, professor, cantora, em família, jogando bola, jogando tênis, médico, skatista, dançarinos, músicos.

- Pessoas indígenas são representadas como: em festas folclóricas, em família, atleta, jogando futebol, mariachis, tocando flauta indígena, comendo no sofá.

- Pessoas asiáticas são representadas como: advogada, aluna, fazendo atividade física, no computador, agricultor, skatista, gueixa, professor de artes marciais.

- Pessoas brancas são representadas como: aluno, professor, cientista, político, filósofo, escritor, padeiro, cantor, cabeleireiro, garçom, técnico em informática, farmacêutico, ator, diretor de cinema, tenista, piloto de F1, arquiteto, caixa de mercado, caminhoneiro, açougueiro, comerciante, dentista, atendente, enfermeira, fotógrafo, guia de turismo, engenheiro, jardineiro, joalheiro, modelo, jornalista, encanador, policial, carteiro, secretária, telefonista, vendedor, veterinária.

Em termos qualitativos, é possível apontar mudanças positivas em relação às demais coleções. Na coleção Contraseña, nenhum ator social é representado apenas por imagem só do rosto, todos apresentam alguma caracterização que permite atribuir papéis sociais às pessoas retratadas; além disso, há maior diversidade de papéis sociais relacionados, principalmente, a pessoas negras e asiáticas, e estes papéis não se limitam aos estereótipos clássicos atribuídos a essas 
raças. Por outro lado, algumas das representações de pessoas indígenas (que já são poucas) perpetuam estereótipos (em festas folclóricas, mariachis, tocando flauta indígena, oferecendo uma planta), retratando pessoas indígenas apenas de forma folclórica, cultural e/ou exótica. As representações de pessoas brancas se mantêm no mesmo padrão das coleções anteriores: com ampla diversidade de papéis sociais.

Seguem abaixo algumas imagens da coleção Contraseña.

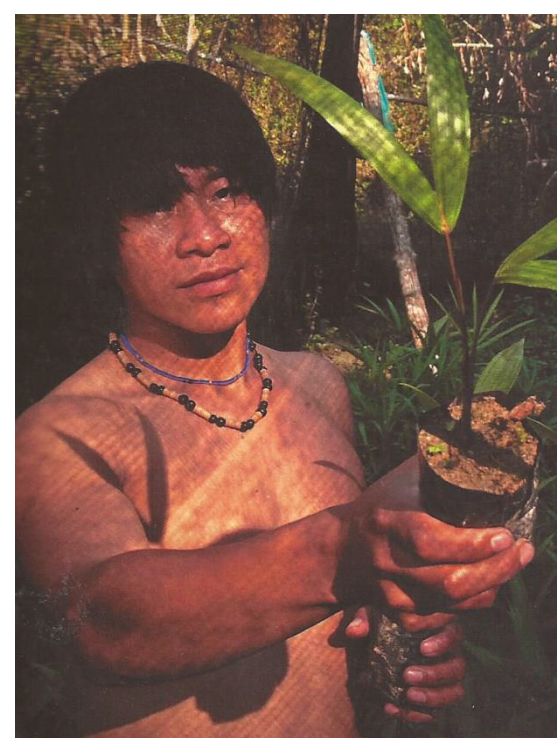

Figura 14. Representação de pessoa indígena: oferecendo uma planta (livro 1, p. 55)

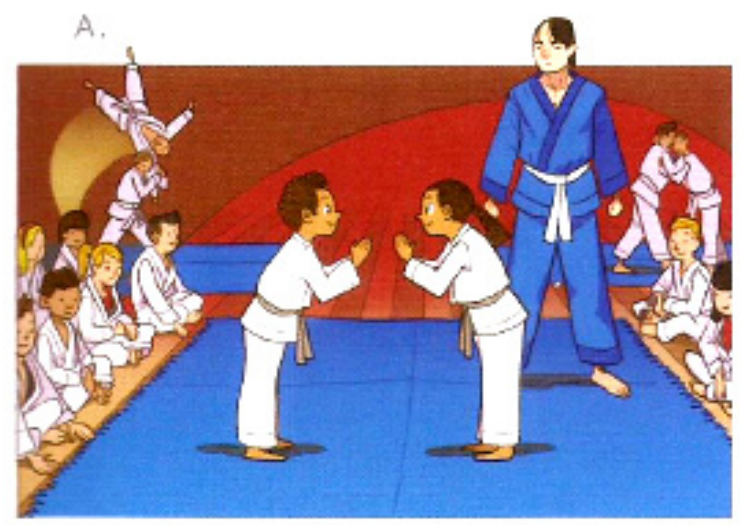

Figura 15. Representação de pessoas asiáticas: professor de artes marciais (livro 2, p. 41)

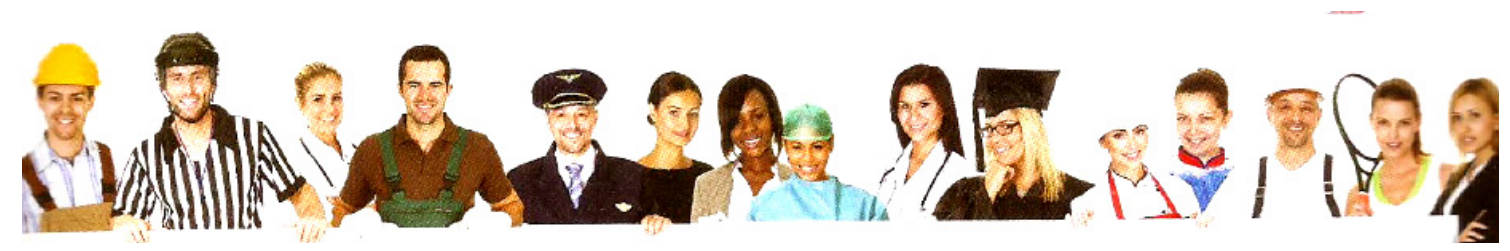

Figura 16. Representação de pessoas brancas e pessoa negra: profissionais de diversas áreas (livro 4, p. 72)

Os dados desta pesquisa corroboram os dos estudos resumidos na seção 2 deste artigo. Assim como nos estudos de Jovino (2014) e Ferreira et. al. (2019) também foram identificadas imagens positivas de representações de pessoas negras, principalmente na coleção Contraseña. Entretanto, assim como nos demais estudos, foi constatada uma enorme desigualdade no número de representações entre pessoas brancas e pessoas de outras raças. Ferreira et. al. (2019) apontam um percentual de representação de negros inferior a 30\%, na coleção Síntesis. Da mesma maneira, os dados da presente pesquisa mostram que negros estão representados em menos de $20 \%$ das imagens nas quatro coleções analisadas. Os dados de Souza (2016) também são confirmados aqui, pois constata-se que, embora pessoas negras sejam representadas em contextos profissionais, afetivos e educacionais, essas representações são pouco frequentes 
nas coleções. Além disso, foram identificadas diversas representações de estereótipos clássicos nas imagens que retratam pessoas negras (negros como atletas, pessoas carentes e africanos primitivos), corroborando dados também encontrados por Enevan e Jovino (2019).

A partir dos dados quantitativos obtidos após análise das quatro coleções, de forma geral, foi possível observar que o número de imagens em que há representação de pessoas negras não chega a $20 \%$, as representações de indígenas e asiáticos não chegam a 10\%, enquanto a representação de pessoas brancas corresponde a pelo menos $80 \%$ em todas as coleções.

Ficou demonstrado que, em mais de uma década (2002 a 2015), não houve mudanças significativas na frequência com que pessoas negras, indígenas, asiáticas e brancas são representadas em imagens nos LD de Espanhol, houve, no máximo, um aumento da variedade de papéis sociais relacionados a elas. Ao longo do tempo, a frequência de representação de pessoas negras foi sutilmente aumentando, a de indígenas e asiáticos se mantêm ínfima, e a de pessoas brancas mostra-se esmagadora em relação às demais. Os dados são compilados no gráfico abaixo.

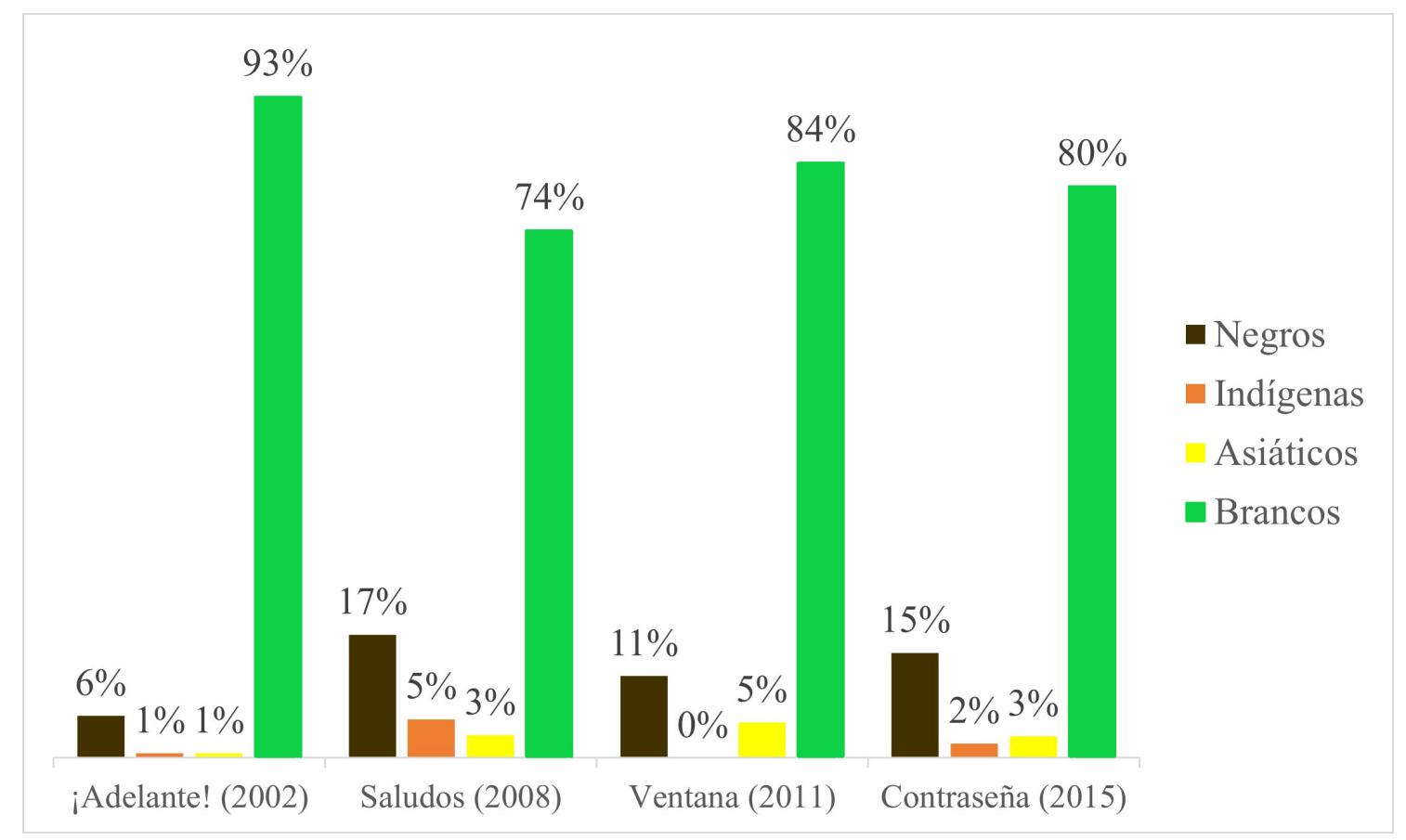

Figura 17. Gráfico do percentual de representações das raças nas quatro coleções

A exclusão de indígenas e a pouca, porém existente, representação de negros nas coleções analisadas corroboram a seguinte afirmação de van Dijk (2008, p. 24):

(...) ao passo que os latino-americanos de origem africana estão sendo discriminados discursivamente de várias maneiras (...) mas geralmente reconhecidos como parte da sociedade, as populações indígenas costumam ser simplesmente ignoradas ou associadas com distância geográfica e atraso ou primitivismo, como se vivessem em "outro tempo", consideradas até mesmo uma raça "menor" em certos livros didáticos e conversas racistas.

No que diz respeito ao modo como atores sociais são representados, as pessoas indígenas estão, praticamente, excluídas das coleções. Nas poucas aparições que há nos LD, indígenas são representados, predominantemente, das seguintes formas:

- culturalmente categorizados (em festas folclóricas, mariachis, tocando flauta indígena);

- homogeneizados em representações que mostram grupos indígenas em festas folclóricas, trajando o mesmo tipo vestimentas, o que induz à ideia de que "eles são todos iguais", criando e/ou reafirmando estereótipos sobre essas pessoas;

- passivizados, pois são representadas sem qualquer agenciamento em imagens que mostram apenas os seus rostos a serem meramente observados pelos espectadores/leitores. 
É certo que pessoas indígenas fazem festas folclóricas, tocam flauta e podem atuar como vendedores de flores, a crítica que se faz aqui é que não são só essas as suas atividades nas sociedades em que vivem. Em muitos dos países hispano-falantes, a população é predominantemente indígena, portanto, essas pessoas atuam em diversos setores da sociedade e não estão somente em festas folclóricas e âmbitos sociais restritos, como sugerem as imagens das coleções. Há médicos, enfermeiros, professores, alunos, cabeleireiros, engenheiros, entre outros profissionais que apresentam traços fenotípicos indígenas. Por que essas pessoas não são retratadas nos LD?

Atores sociais asiáticos também estão, praticamente, excluídos das coleções. Nas poucas representações que há nos LD, eles são:

- culturalmente categorizados (alunos, gueixa, professor de artes marciais);

- estereotipados (nesse caso, até positivamente) pela representação, em todas as coleções, de asiáticos como alunos, sugerindo o estereótipo do asiático (principalmente japonês) estudioso, inteligente;

- passivizados em imagens que os retratam apenas pelo rosto, prescindindo de agenciamento, expostos tão somente para observação dos espectadores.

Atores sociais negros são representados das seguintes formas:

- genericamente como pessoas que representam certos tipos sociais: os bons atletas (jogadores de futebol, de basquete, atletas de corrida), a integrante de escola de samba, os africanos miseráveis, os profissionais de atividades socialmente desprestigiadas (taxista, grafiteiro);

- culturalmente categorizados (africanos em festa, dançarina de carnaval);

- homogeneizados (grupo de africanos todos pintados da mesma maneira, fila de pessoas negras miseráveis, jogadores de futebol), o que reforça estereótipos e a demarcação desses papéis sociais para pessoas negras;

- passivizados, desprovidos de agenciamento, quando são retratados apenas pelo rosto.

Atores sociais brancos são representados em diversos papéis sociais, sendo caracterizados muito mais como agentes do que em posição de passividade. Além disso, têm representações muito mais individualizadas e específicas (não são retratadas de forma homogeneizada por atributos padronizados, como trajes típicos, por exemplo). A alta frequência com que figuram nas coleções e a diversidade de representações em que se apresentam, certamente, favorecem a idealização de identidades sociais positivas sobre pessoas dessa raça.

Já a exclusão de atores sociais indígenas, asiáticos e a pouca representação de negros, bem como a estereotipação negativa dessas raças, contribui para a idealização de que essas pessoas são "o outro", as identidades sociais negativas e/ou indesejadas, com papéis sociais demarcados e, muitas vezes, subalternizados.

Sobre a construção de identidades sociais negativas em decorrência de representações racistas, Ferreira (2012, p. 205) alerta que

A forma como as identidades sociais estão representadas têm desdobramentos sociais tanto para negros como para não negros. Para os negros, traz o desejo de não pertencimento, (...), para os não negros, a imagem pode impedir que as pessoas tenham um olhar positivo acerca dos aspectos culturais e de identidade dos africanos, afro-brasileiros ou negros.

Dessa forma, para que esse tipo de ideologia não se reproduza, mas seja desconstruída, é preciso diversificar as representações de atores sociais, contemplando, quantitativa e qualitativamente todas as raças de forma equânime, oferecendo representações socialmente positivas e problematizando representações socialmente desvalorizadas. Como afirma Ribeiro (2019), a questão é de representatividade e proporcionalidade. Referindo-se ao ambiente de trabalho, essa autora ressalta que a baixa presença de pessoas negras, tanto no ambiente como em posições de poder, pode favorecer a ocorrência de violências racistas. $\mathrm{O}$ mesmo pode ser pensado sobre o ambiente escolar e os materiais didáticos.

Por fim, cabe ressaltar a incoerência da exclusão de pessoas indígenas e negras nas representações de atores sociais dos LD analisados, haja vista que o Espanhol é a língua oficial de diversos países cuja população é predominantemente indígena e possuem também um contingente significativo de pessoas negras (cf. SOUZA, 2016). Ao tratar da categoria exclusão, van Leeuwen (2008) salienta que o não reconhecimento da existência de pessoas ou tipos de pessoas que vivem entre nós é uma forma simbólica de exclusão social. Em concordância com essa alegação do autor, conclui-se que, ao reproduzirem em suas imagens discursos excludentes, por meio de mecanismos 
de exclusão, passivização, homogeneização de pessoas negras, indígenas e asiáticas e representação quase exclusiva da branquitude, as coleções analisadas não contribuem para minimizar ou combater o racismo no ambiente escolar e, consequentemente, na sociedade.

\section{CONSIDERAÇÕES FINAIS}

Tendo em vista o crescente espaço que os textos imagéticos vêm ocupando em inúmeros suportes, gêneros e tipos discursivos, dos mais diversos campos sociais, não se pode ignorar ou simplificar a importância das imagens (tanto quanto do texto verbal) na representação da realidade e nos processos de identificação de atores sociais, em uma sociedade cada vez mais visual. Da mesma maneira, é preciso sublinhar, conforme já mencionado, a influência dos LD enquanto transmissores de conhecimento. Esses materiais ainda são vistos como portadores de autoridade para determinar o que é real e verdadeiro e, assim, colaboram na formação moral e intelectual dos estudantes a partir da sua ação de legitimação de verdades na escola e na sociedade.

Nesse aspecto, cabe compreender que dificilmente os LD estarão isentos de concepções hegemônicas ou ideológicas, uma vez que a produção e a comercialização desses materiais envolvem atores sociais e demandas institucionais (editais de seleção, interesses do mercado editorial, orientações pedagógicas das escolas etc), os quais têm seus posicionamentos políticos, que vão estar refletidos de alguma maneira nos LD.

Entretanto, faz-se necessário que todos os agentes envolvidos e interessados no processo educacional estejam atentos e aptos a problematizar os discursos (re)produzidos pela escola, haja vista o poder simbólico que esta instituição representa na construção do conhecimento e de certas verdades sociais. O discurso escolar se manifesta de diversas maneiras, por diversos gêneros discursivos produzidos no ambiente escolar, os quais formam uma rede de textos que, em maior ou menor grau, orientam maneiras de pensar e atuar na sociedade. Assim, é imprescindível que as práticas discursivas escolares, através de seus atores sociais e de seus artefatos (como os materiais didáticos, p. ex.), possam estar politicamente comprometidas com a desconstrução e o combate de problemas sociais complexos como o racismo.

Apesar da constatação de que LD produzidos ao longo de mais de uma década não apresentaram mudanças significativas em relação à representação de atores sociais de diferentes raças, mudanças estão a caminho. O livro Contraseñas, por exemplo, apresenta maior diversidade de papéis sociais para pessoas de diferentes raças e relaciona pessoas negras a atividades socialmente valorizadas, o que não constava nas coleções produzidas anteriormente. Portanto, embora as mudanças positivas venham mais lentas do que se espera, elas estão a caminho.

Nesse sentido, vale retomar um pressuposto da ADC: a linguagem molda a sociedade e é moldada por ela. O discurso se constitui dialeticamente nas práticas sociais. Dessa forma, como afirma Vieira (2019, p. 85), "práticas escolares de produção e circulação de conhecimentos podem contribuir para manter, mas também para problematizar e superar relações de opressão.".

Diante de problemáticas como as mostradas neste estudo, atores sociais da educação podem assumir uma postura decolonial e promover discussões sobre as imagens presentes nos LD, sensibilizando o olhar dos alunos para questões como as que foram assinaladas neste artigo. Podem também produzir e/ou introduzir materiais complementares ao LD e que apresentem outras representações de atores sociais, mais adequadas à realidade e aos interesses dos alunos, a fim de desconstruir e desnaturalizar processos de identificação social "construídos para nós, e não por nós" (parafraseando FERREIRA, 2012, p. 209).

\section{REFERÊNCIAS}

ALMEIDA, Adriana Pedro de; AMENDOLA, Roberta.(2011). Ventana al español. São Paulo: Moderna. v. 1, 2,3 e 4.

ARTUÑNEDO, Belén; DONSON, Cynthia. (2002). iAdelante! Comunicación en español. São Paulo: FTD. v. 3 e 4.

BOROBIO, Virgilio. (2002). iAdelante! Comunicación en español. São Paulo: FTD. v. 1 e 2.

CALLEGARI, Marilia Vasques; RINALDI, Simone. (2015). Contraseña. São Paulo: Moderna. v. 1, 2, 3 e 4. 
ENEVAN, Edina Aparecida da Silva; JOVINO, Ione da Silva. (2019). Representações de identidades sociais de gênero, raça e classe em livros didáticos de espanhol à luz da análise crítica do discurso. UNILETRAS, v. 1. p. 25-39

FAIRCLOUGH, Norman. (1992). Discurso e mudança social. [Coord. de tradução: Izabel Magalhães] Brasília: Editora da UnB, 2016.

FERREIRA, Aparecida de Jesus; FERREIRA NETTO, Letícia Camargo; OLIVEIRA, Keila de. (2019). Algumas considerações sobre a importância da representação de raça, gênero e classe social em um livro de espanhol. UNILETRAS, v. 41, p. 10-24.

FERREIRA, Aparecida de Jesus. (2012). Identidades sociais, letramento visual e letramento crítico: imagens na mídia acerca de raça/etnia. Trabalhos em Linguística Aplicada. v. 51. p. 193-215.

JOVINO, Ione da Silva. (2014). Representação de negros e negras num livro didático de Espanhol: alguns apontamentos. In: FERREIRA, Aparecida de Jesus (org). As políticas do livro didático e identidades sociais de raça, gênero, sexualidade e classe em livros didáticos. Campinas, SP: Pontes Editores. p. 121-141.

KRESS, Gunther; VAN LEEUWEN, Theo. (2006). Reading Images. The grammar visual design. London; New York: Routledge.

MARTIN, Ivan Rodrigues. (2008). Saludos: curso de lengua española. São Paulo: Ática. v. 1, 2, 3 e 4.

MELO, Iran Ferreira de. (2009). Análise do discurso e análise crítica do discurso: desdobramentos e intersecções. Letra Magna. v. 1 . Ano 05, n.11. e

OLIVEIRA, Sara. (2008). Texto visual, estereótipos de gênero e o livro didático de língua estrangeira. Trabalhos em Linguística Aplicada. vol.47, n.1, p. 91-117.

RESENDE, Viviane de Melo. (2019) Perspectivas latino-americanas para decolonizar os estudos críticos do discurso. In: RESENDE, Viviane de Melo. (Org.). Decolonizar os estudos críticos do discurso. Campinas: Pontes. p. 19-46.

RIBEIRO, Djamila. Pequeno manual antirracista. (2019). São Paulo: Companhia das Letras.

SILVA, Francisca Cordelia Oliveira da. (2011). Análise do discurso crítica como aporte para um estudo do racismo no Brasil. Brasília: Editora Kiron.

SILVA, Paulo Vinicius Baptista da; TEIXEIRA, Rozana; PACÍfICO Tânia Mara. (2014). Programas de distribuição de livros e hierarquias raciais: o que dizem os alunos negros/as? In: FERREIRA, Aparecida de Jesus (org). As políticas do livro didático e identidades sociais de raça, gênero, sexualidade e classe em livros didáticos. Campinas, SP: Pontes Editores. p. 23-45.

SOUZA, Josane Silva. (2016). Identidades negras no livro didático de espanbol. Dissertação de mestrado. Instituto de Letras, UFBA, Salvador.

VAN DIJK, Teun A. (2008). Racismo e discurso na América Latina. São Paulo: Contexto.

VAN LEEUWEN, Theo. (2008). Discourse and Practice: new tools for critical discourse analysis. New York: Oxford University Press.

VIEIRA, Viviane. (2019). Perspectivas decoloniais feministas do discurso na pesquisa sobre educação e gênero-sexualidade. In: RESENDE, Viviane de Melo. (Org.). Decolonizar os Estudos Críticos do Discurso. Campinas: Pontes. pp. 83-116.

VIEIRA, Viviane Cristina; RESENDE, Viviane de Melo. (2016) Análise de discurso (para a) crítica: o texto como material de pesquisa. 2. ed. Campinas: Pontes.

Recebido: $31 / 10 / 2021$

Aceito: 29/3/2021

Publicado: 3/8/2021 